\title{
レーザー誘起熱応力を利用した板ガラスの分断加工のシミュレーション
}

\author{
八幡 恵輔，清水 政二，村上 政直 \\ 三星ダイヤモンド工業株式会社 ( ₹566-0034 大阪府摂津市香露園32-12)
}

\section{Analysis of Cutting Glass Sheets by Laser-Induced Thermal Stress}

\author{
Keisuke YAHATA, Seiji SHIMIZU, and Masanao MURAKAMI \\ Mitsuboshi Diamond Industrial CO.,LTD., 32-12 Koroen, Settsu, Osaka 566-0034
}

(Received August 13, 2016)

\begin{abstract}
Scribing, or the full-body cutting of glass substrates, can be achieved by thermal stress that is induced by laser heating. In such processing, the substrate's temperature distribution is controlled by scanning the heat source or a pair of heat and cooling sources for generating sufficiently high tensile stress to propagate a crack. As a result of crack propagation that follows the laser beam, the substrate can be divided along the laser beam scanning path. By analyzing the temperature and the thermal stress in the numerical simulations, we can estimate suitable processing conditions. How the crack propagates can also be estimated by analyzing the stress intensity factors. Numerical simulations supported clarifying the mechanism of crack propagation and devising new processing methods for controlling crack propagation.
\end{abstract}

Key Words: Laser, Thermal stress, Glass, Cutting

1.はじめに

電子部品やディスプレイなどの製造にはガラス基板を 分断する工程が不可欠である. ガラスのような脆性材料 は，分断予定線に沿って表面に亀裂を形成した後，亀裂 に沿って応力を加えることで分断できる，亀裂を形成す る工程をスクライブといい, この加工後に分断する工程 をブレイクという。このようなスクライブ・ブレイク方 式の他に, 基板の厚さ方向に貫通した亀裂を分断予定線 に沿って成長させる，フルカット加工もある。フルカッ ト加工ではブレイク工程は不要である.

レーザー加熱によって生じる熱応力を利用してガラス 基板に亀裂を形成できる。このときの温度分布の違いに よってスクライブ加工1,2) かフルカット加工范年かが決ま る. 熱応力を利用したガラスの分断加工は, 分断された 基板の高い端面強度が保たれる点に大きな利点がある。 この加工に扔ける亀裂進展現象は, 有限要素法や境界要 素法を用いた解析によって理論的に説明されている。

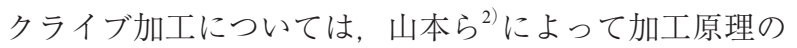
説明がなされ，著者ら ${ }^{5,6}$ は亀裂の深さや形状を予測す る研究を行ってきた。 フルカット加工については, Tsai

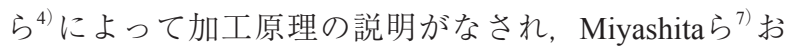
よび本村ら ${ }^{8}$ によって分断経路を予測できることが示さ れている. 本稿では, 熱応力を利用したガラス基板の分 断に関する解析の事例を解説する。

\section{2. 熱応力を利用したガラス基板の分断加工}

熱応力によるガラス基板の分断法の模式図をFig. 1に 示す，スクライブ，フルカット加工のいずれも，まず加 工開始位置にガラスカッターなどで小さな初期亀裂を形 成する。次に，スクライブ加工では， $\mathrm{CO}_{2}$ レーザー(波

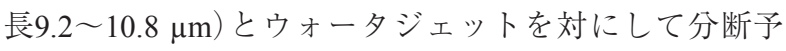
定線に沿って走査させる. $\mathrm{CO}_{2}$ レーザー光のガラスに対 する消衰係数は $0.1 \sim 1$ 程度であり ${ }^{9)}, \mathrm{CO}_{2}$ レーザー光は ガラス基板の表面近傍で吸収される。 その後, 熱伝導に よって基板が表面から内部にかけて加熱される。 その直 後に基板表面が冷却される結果，基板表面は内部に対し て低温となる。このようにして基板の厚さ方向に温度勾 配が形成され，基板表面に引張応力が生じ，レーザー走 査経路に沿って初期亀裂が成長する2).ガラス内部には 圧縮応力が生じ, 亀裂は基板の厚さ方向に貫通すること なく，一定深さで形成される，スクライブ加工では，加

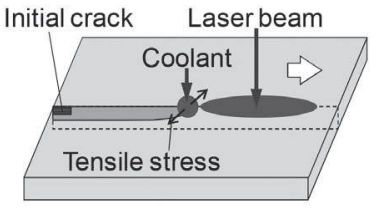

(a) Scribing

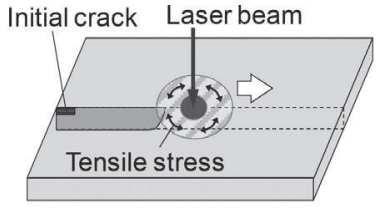

(b) Full-body cutting
Fig. 1 Schematics of crack propagation processing by laser-induced thermal stress. 
工速度が速い場合でも基板の内部まで加熱されるよう， Fig. 1(a)のようにレーザー光を楕円形に成形することが 多い.

フルカット加工では，初期亀裂を形成した後，加熱源 であるレーザー光のみを分断予定線に沿って走査させ る. 基板が局所的に加熱され，レーザー照射面内で温度 勾配が生じ，レーザー照射位置の周囲に引張応力がはた らく，その結果，初期亀裂がレーザー光に追従するよう に進展して分断線が形成される は，基板の表面から裏面まで十分に加熱する必要があ り, $\mathrm{CO}_{2}$ レーザーやYAGレーザー(波長1.064 $\mu \mathrm{m}$ ) が用い られる。 $\mathrm{CO}_{2}$ レーザーの場合, レーザー光はガラスの表 面近傍で吸収されるため, レーザー照射面の温度が裏面 に比べて高くなる。これに対してYAGレーザーの場合は, ガラスに対する消衰係数が $0.5 \sim 1 \times 10^{-7}$ 程度であり ${ }^{9)}$, ガラスを透過しながら一部のエネルギーが吸収されるた め, 表面と裏面の温度差が比較的小さくなる，基板が厚 い場合など，基板表面の過剩な温度上昇を抑えて裏面ま で十分に加熱するには， $\mathrm{CO}_{2}$ レーザーよりYAGレーザー の方が適している。

熱応力を利用して形成されたガラス基板の分断面を Fig. 2に示す. Fig. 2(a) は，スクライブ加工後にブレイ クして形成された断面である. スクライブ加工で一定深 さの亀裂が形成された痕が図中矢印部分に見られる。 Fig. 2(b)はフルカット加工で形成された断面であり， ス クライブ加工の場合のような亀裂の痕は見られない。い ずれの加工も加工部に欠陥が発生せず，分断された基板 の端面強度が高く保たれる。 スクライブ加工には棈円形 のレーザー光が使用されるため, 曲線状の分断には不向 きであるが, $1000 \mathrm{~mm} / \mathrm{s}$ 程度の速い加工速度と高い加工 精度が得られる点で, 直線状の分断に適している。フル カット加工は, レーザー光を曲線状に走査させることで 曲線状の分断が可能である点に利点がある。

\section{3. 数値解析による亀裂進展の評価}

\section{1 応力拡大係数による亀裂進展の評価}

熱応力を利用したガラス基板の分断は, 基板内で亀裂 を進展させる加工である，破壊力学の考えに基づけば,

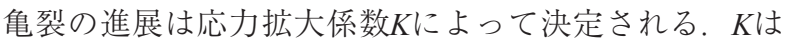
曲率半径が限りなく 0 に近い亀裂の先端近傍の応力場を 記述するためのパラメータであり, 龟裂形状および作用

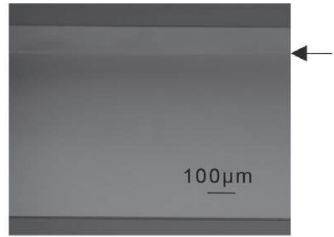

(a) By scribing and breaking

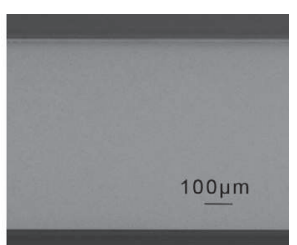

(b) By full-body cutting
Fig. 2 Cutting planes of glass sheets created by thermal stress processing.
する応力から求められる。亀裂に作用する応力が大きい ほどKが増加し，Kが破壊勒性 $K_{\mathrm{C}}$ を超えると亀裂が進展 する．Fig. 3のような座標系をとるとき，亀裂面に対す る垂直応力 $\left(x_{2}\right.$ 方向応力)による亀裂の進展はモードIの

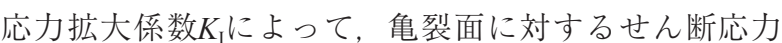

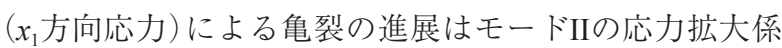
数 $K_{\mathrm{II}}$ によって評価される。亀裂面に垂直応力とせん断 応力が同時に作用する場合,

$$
K=\left(K_{\mathrm{I}}^{2}+K_{\text {II }}^{2}\right)^{0.5} \geq K_{\mathrm{C}}
$$

であれば亀裂が進展する ${ }^{10)}$ 。このとき，せん断応力は亀 裂を湾曲させるはたらきを持ち,

$$
\theta=2 \tan ^{-1}\left\{\frac{1}{4}\left[\frac{K_{\mathrm{I}}}{K_{\mathrm{II}}} \mp \sqrt{\left(\frac{K_{\mathrm{I}}}{K_{\mathrm{II}}}\right)^{2}+8}\right]\right\}
$$

によって計算される方向へ亀裂が進展する ${ }^{11)}$ 。なお, $K_{\mathrm{II}} \equiv 0$ の場合，亀裂は湾曲せずにまっすぐ進展する.

\section{2 数值解析による応力拡大係数の計算}

長さ $a$ の直線状の亀裂に一様な引張応力 $\sigma_{0}$ が作用する 場合,

$$
K_{\mathrm{I}}=\sigma_{0} \sqrt{\pi a}
$$

と表わされる ${ }^{10)}$ 。 しかし, 応力分布が不均一な場合や亀 裂が湾曲する場合などは，応力拡大係数を簡単に求めら れず，有限要素法や境界要素法による計算が試みられ， その有効性が示されている ${ }^{12-18)}$. 数值解析による応力桩 大係数の計算方法の一つに，変位外挿法がある．Fig. 3に おいて $\theta=+\pi$ を満たす亀裂面上の任意点の変位 $\left(u_{\mathrm{x} 1}, u_{\mathrm{x} 2}\right)$ は，

$$
\begin{aligned}
& u_{\mathrm{x} 1}=\frac{K_{\mathrm{II}}}{2 G} \sqrt{\frac{\left|x_{1}\right|}{2 \pi}}(\kappa+1) \\
& u_{\mathrm{x} 2}=\frac{K_{\mathrm{I}}}{2 G} \sqrt{\frac{\left|x_{1}\right|}{2 \pi}}(\kappa+1)
\end{aligned}
$$

ただし，

$\kappa= \begin{cases}3-4 v & \text { 平面ひずみ } \\ (3-v) /(1+v) & \text { 平面応力 }\end{cases}$

と表わされる ${ }^{10)}$ 。なお， $G$ は剛性率， $v$ はポアソン比で ある。すなわち, 解析によって変位場 $\left(u_{\mathrm{x} 1}, u_{\mathrm{x} 2}\right)$ が求ま れば, 応力拡大係数 $K_{\mathrm{I}}, K_{\mathrm{II}}$ を求められる.

熱応力を利用したガラス基板の分断加工については, まずレーザー加熱やウォータジェットでの冷却を受けた 基板の温度分布の時間変化を求め, 次に温度分布を基に 基板のひずみ，および熱応力分布を求め，その後応力拡

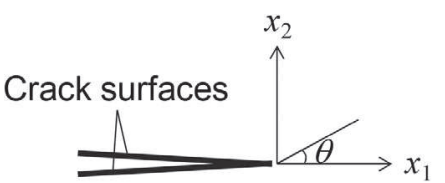

Fig. 3 Coordinate system around a crack tip. 
大係数を求めることで, 亀裂の進展を評価できる.

\section{3 有限要素法と境界要素法}

数值解析によって応力拡大係数 $K$ を求める際, $K$ の精 度は変位場および応力場の解析精度に依存する。有限要 素法によるKの計算手法は古くから研究され ${ }^{12,13)}$, Barsoumの特異要素 ${ }^{14)}$ など, 亀裂先端近傍の応力場をより 正しく求めるための方法が提案されている。ただし，三 次元問題で亀裂サイズが大きい場合などは, 亀裂先端周 辺の要素を十分小さくすると要素数が増え, メッシュ生 成および解析のコストが高くなる，特に，時間経過と共 に亀裂が成長する過程を解析する場合は，メッシュ生成 とKの計算を繰り返しながら解析を進める必要があり, 解析コストが一つの課題となる.

メッシュ生成のコストを下げる数值解析法として境界 要素法がある。境界要素法は, 支配微分方程式を境界積 分方程式に置き換えることで，モデル表面のみの要素分 割によって解を得ることができる。つまり，面要素によ る三次元解析や線要素による二次元解析が可能となり, メッシュ生成が簡略化される。亀裂問題において最も重 要なものは，モデル表面上に位置する亀裂先端の解であ るため, 表面の要素のみを扱う境界要素法は相性の良い 解析手法といえ，多くの研究が行われている ${ }^{15-18)}$.

\section{4. 熱応力を利用したスクライブ加工の数值解析}

\section{1 適正加工条件の推定}

熱応力を利用したガラスのスクライブ加工の代表的な 利点として，速い加工速度で高い端面強度が得られるこ とが挙げられる。ただし, そのためには適切な加工条件 を選択する必要がある。たとえば，レーザー加熱によっ て基板がガラス転移点以上に加熱されると, 加熱域に残 留応力が生じる。残留応力が大きすぎると欠陥が発生 し, 分断された基板の端面強度が著しく低下する. 逆に レーザー加熱が不十分な場合には，亀裂が形成されず, スクライブ加工が成立しない。このようにして決まる適 正加工条件は，ガラスの種類や板厚によって変わる．例 として, 厚さ $0.7 \mathrm{~mm}$ のーダライムガラスとアルミノ シリケートガラスの適正加工条件をFig. $4^{19)}$ に示す. は欠陥が生じた条件を，×は亀裂が形成されなかった条 件を，○は欠陥の発生なく亀裂が形成された条件(適正

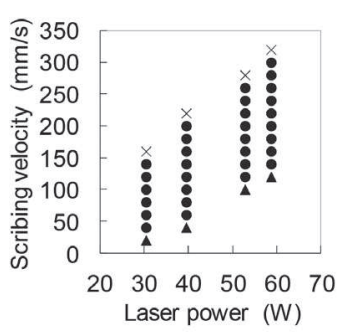

(a) Soda-lime glass

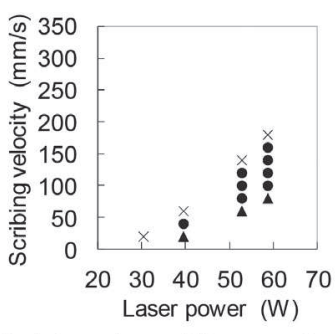

(b) Aluminosilicate glass
Fig. 4 Process window in thermal stress scribing for soda-lime glass and aluminosilicate glass.
加工条件)を意味する. Fig. 4に示した二種類のガラスの 適正加工条件を比較すると，アルミノシリケートガラス は，走査速度が比較的遅い場合でも欠陥が発生しないこ と，拈よ゙，ソーダライムガラスは，走査速度が比較的 速い場合でもスクライブ加工が成立することがわかる.

これらの実験結果を有限要素解析で求めた加工中の温 度および熱応力と比較することで，以下の二点が明らか になった ${ }^{2,19,20)}$. (1)加工中の基板温度が一定值を超えた 場合, 残留応力によって久陥が生じる。(2)加工中の引張 応力の最大值が一定值を下回った場合, 亀裂が進展しな い.これらを踏まえると, Fig. 4に示した適正加工条件 の違いについて，以下のように説明できる。アルミノシ リケートガラスはソーダライムガラスに比べてガラス転 移点が高く，基板が高温まで加熱されても残留応力が生 じにくいため, 走査速度が比較的遅くても欠陥が生じな い.ソーダライムガラスはアルミノシリケートガラスに 比べて線膨張係数が高く，基板を高温まで加熱しなくて も大きな熱応力が生じるため, 加工速度が速くても亀裂 が形成される。熱物性および機械物性が既知の材料であ れば，解析による適正加工条件の予測が可能であり，新 たな材料に対する加工条件を選定する際の目安にでき る。

\section{2 亀裂深さおよび形状の推定}

熱応力を利用したスクライブ加工において, Fig. 2(a) のように分断面を顕微鏡などで観察することで亀裂深さ を測定できる。亀裂深さは加工条件によって変化し，そ の一例として，厚さ $0.7 \mathrm{~mm}$ のソーダライムガラスに対 して形成された亀裂深さの測定結果をFig. $5^{5)} に$ 示す。な お，本節で説明する有限要素解析による亀裂深さの予測 結果も併せて示した。一般に，レーザー出力が高く走査 速度が遅いほど，深い亀裂が形成される。このように変 化する亀裂深さを予測するための解析のフローチャート をFig. 6に示す。このフローチャートは，第2章で述べた スクライブ加工の原理に基づく，亀裂は，その先端には たらく引張応力によって進展し, 基板内部にはたらく圧 縮応力によって進展が抑制される。つまり，亀裂が浅い

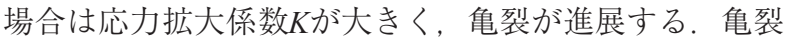
が深く進展するに伴ってKが低下し，あるしきい值 $K_{\mathrm{th}}$ を

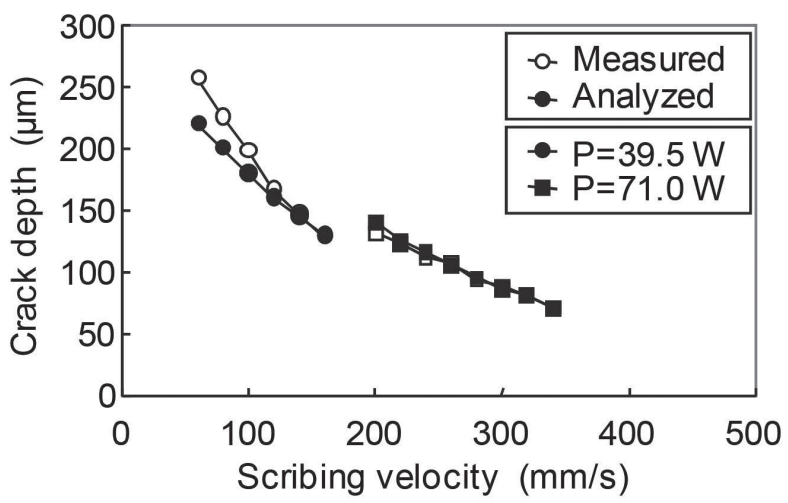

Fig. 5 Crack depth formed by thermal stress scribing. 


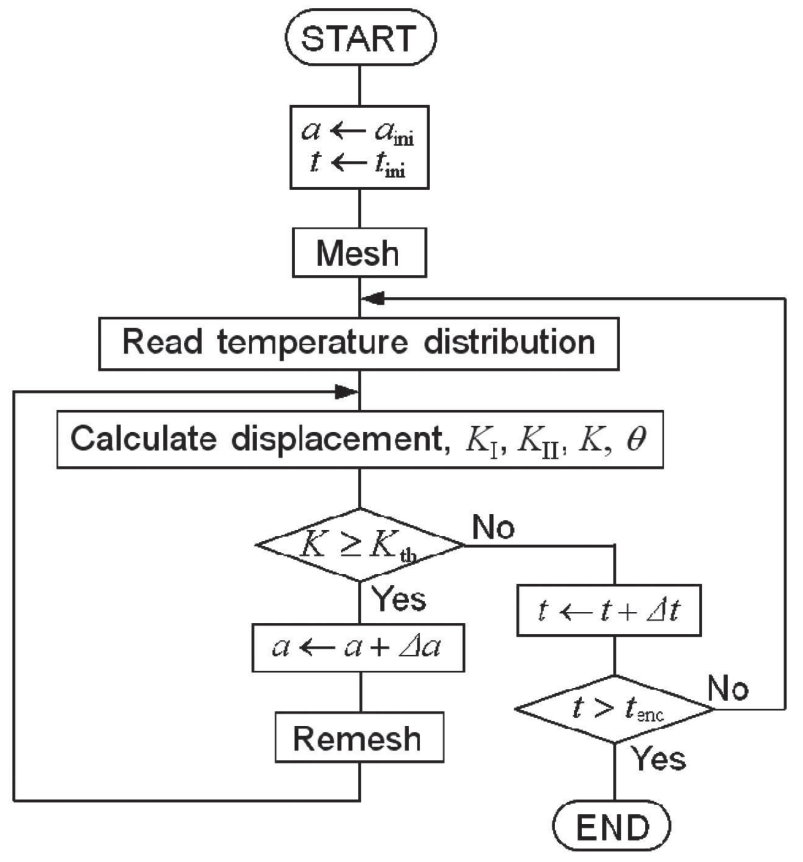

Fig. 6 Flowchart to analyze how far a crack propagates in thermal stress scribing.

下回ると，それ以上進展しなくなる。 そこで解析におい ては, 初期亀裂深さを $a_{\mathrm{ini}}$ とし，Kが $K_{\mathrm{th}}$ を超えた場合は, 式(2)によって計算される $\theta$ の方向へ $\Delta a$ ずつ亀裂を進展

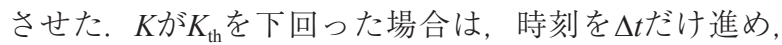
次の時刻へ移った。加工終了時刻 $t_{\mathrm{end}}$ まで解析を進めた ときの亀裂深さを, 解析による予測值とした。この方法 により，Fig. 5のように，実験と解析で亀裂深さの良い 一致が得られることが示された。

熱応力を利用したスクライブ加工において, 加熱位置 と冷却位置のずれにより, 亀裂が板厚方向に対して湾曲 する場合がある. Fig. $7^{6)}$ は，加熱域の中心が $x \equiv 0$ あ゙り， 冷却域の中心が $x \equiv 600 \mu \mathrm{m}$ にずれた状態でスクライブさ れた基板の分断面形状の測定結果である. $0 \leq z \leq 160 \mu \mathrm{m}$ の領域がスクライブ加工で形成された亀裂であり, $160 \mu \mathrm{m} \leq z \leq 700 \mu \mathrm{m}$ の領域はブレイク工程で形成された 面である. 亀裂面 $(0 \leq z \leq 160 \mu \mathrm{m}$ の領域) は90 $\mu \mathrm{m} \leq x \leq$ $100 \mu \mathrm{m}$ の領域に位置し, 加熱域の中心 $(x=0)$ と冷却域の
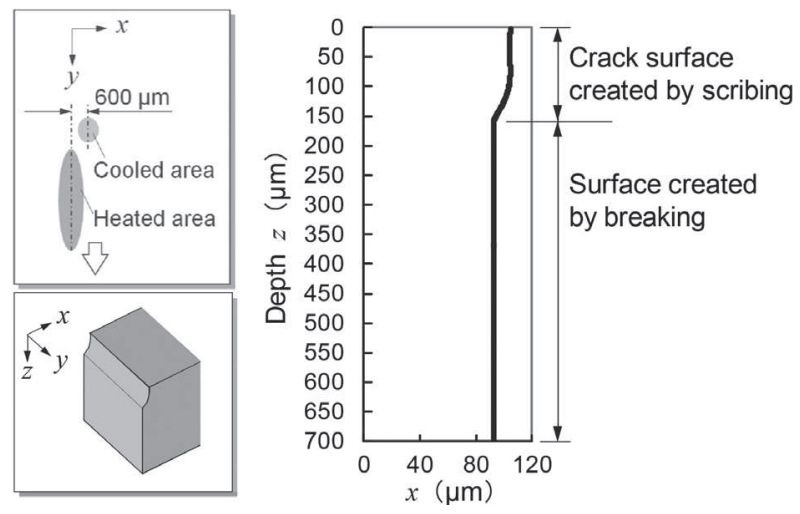

Fig. 7 Example of measured cutting surface profile.
中心 $(x \equiv 600 \mu \mathrm{m})$ との間に亀裂が形成されたことがわか る。著者ら ${ }^{6}$ は, このような湾曲した亀裂面の形状を推 定するため, 有限要素解析で求めた熱応力を基に境界要 素解析で応力拡大係数を求め, 亀裂進展を評価した。境 界要素解析の進行過程の一例をFig. 8に示す。 $z=0$ は基 板表面を意味し，レーザー走査方向はyが正の方向であ る. 解析のフローチャートはFig. 6と同様である. なお, 解析コストを下げるため, 解析領域は細かく分割されて いる。 まず解析領域Iを対象に解析を進め, Step4-1にお いて解析領域Iの全域で $K<K_{\mathrm{th}}$ となり, それ以上亀裂が進 展しなくなった。そこでStep4-2として，解析領域IIへ 移って解析を継続した。

スクライブ加工中, 冷却域の中心が $y=10 \mathrm{~mm}$ の位置 まで走査されたときの亀裂形状の解析結果をFig. 9に実 線で示す. $8.5 \mathrm{~mm} \leq y \leq 11.5 \mathrm{~mm}$ の領域が冷却域で, 加 熱域は $12 \mathrm{~mm} \leq y \leq 38 \mathrm{~mm}$ の領域である。 なお, 解析で は, 深さ30 $\mu \mathrm{m}$ の初期亀裂を解析領域全域に設定した。 この結果から，スクライブ加工中の亀裂は, Fig. 9左図
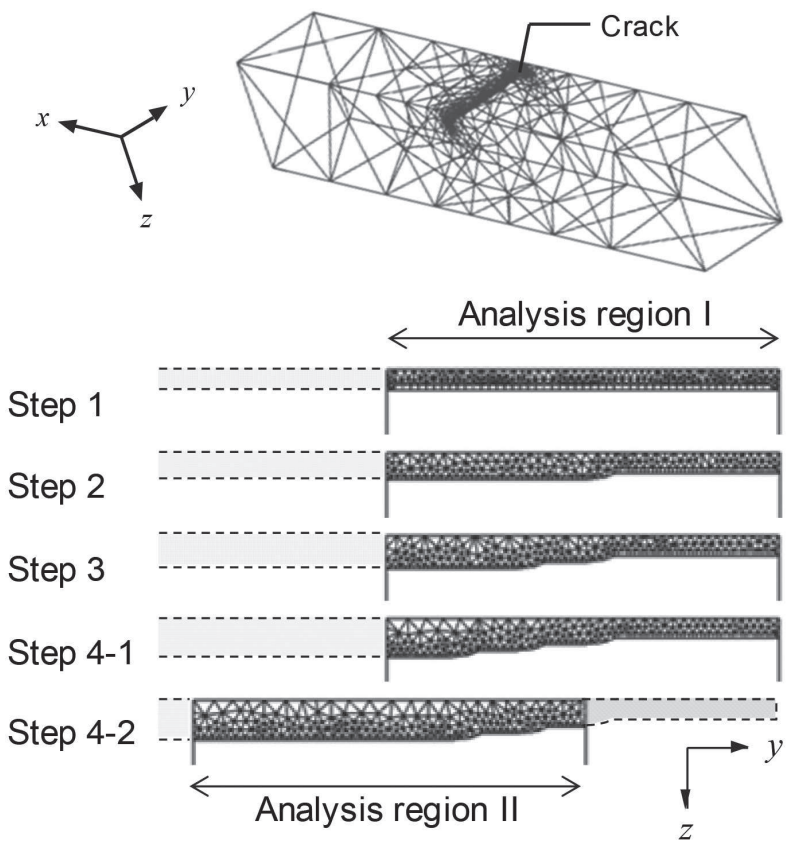

Fig. 8 Example of variation of crack meshing with the progression of the analysis.

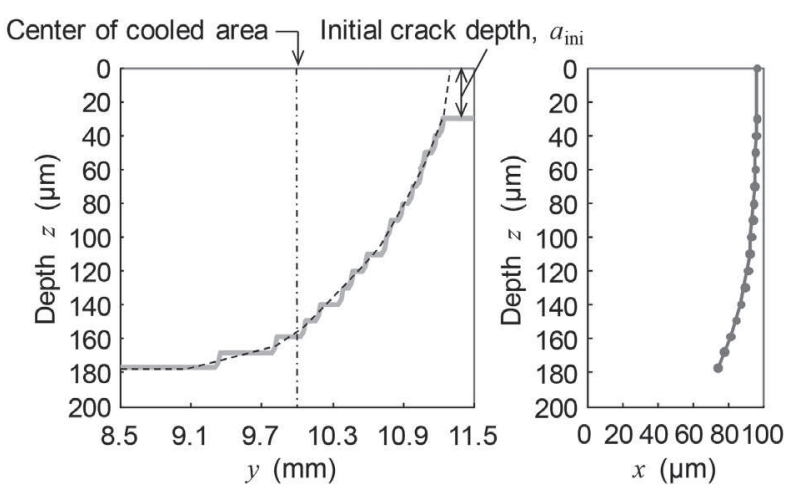

Fig. 9 Example of crack shape obtained by analysis. 
中の破線のような形状でyが正の方向へ進展すると推定 された. Fig. 9の右図に示す亀裂の湾曲形状は, 実測し た亀裂面の形状 (Fig. 7中 $0 \leq z \leq 160 \mu \mathrm{m}$ の領域) とよく一 致した。

以上のように，スクライブ加工で形成される亀裂の深 さや形状を解析によって子測でき, 所望する亀裂を形成 するための加工方法を解析によって検討することができ る.

\section{5. 熱応カを利用したフルカット加工の数值解析}

熱応力を利用したガラス基板のフルカット加工は, レーザー光を曲線状に走査させることで，基板を曲線形 状に分断できる点に利点がある。ただしこの加工には， レーザー走査経路から少しずれた位置で基板が分断され るという特徵がある る,7,8,21) $^{2}$ レーザー走査経路と亀裂進 展経路の関係について, Fig. 10に模式的に例を示す. レーザー走査経路が直線であっても曲線であっても, 亀 裂進展経路のズレが生じる。ズレ量には再現性があり, レーザー出力および走査速度, 基板サイズ, レーザー走 査経路の曲率など，多くのパラメータが影響する.

このようなレーザー走査経路からずれた位置の亀裂進 展についても，有限要素解析で応力拡大係数を評価する ことで理論的な説明がなされている7,8). Fig. 10の例はい ずれも，レーザー走査経路の両側で基板の形状が非対称 である，この場合，亀裂がレーザー走査経路上を進展す ると仮定すると, せん断応力によってモードIIの応力拡 大係数 $K_{\mathrm{II}}$ が 0 でなくなる。このとき，式(2)で計算され る角度だけ湾曲して亀裂が進展するため, 亀裂はレー ザー走査経路上を進展できない。レーザー走査経路から ずれた位置に $K_{\mathrm{II}}$ が 0 となる位置が存在し，亀裂はその位 置を進展することが明らかにされている ${ }^{8)}$.

所望する経路に沿って基板を分断する方法の一つは, あえてレーザー走査経路を分断予定経路からずらすこと である。レーザー走査経路をどの程度ずらすべきか, 数 值解析によって事前に予測することで，最適なレーザー 走査経路の探索を簡略化することができる。また，レー ザー光を長方形状に成形する方法や二つのレーザー光を 用いる方法 ${ }^{8}$ も提案されている. これらの方法は, 温度 分布および応力分布を分断予定経路に対して非対称にす ることで， $K_{\mathrm{II}}$ が 0 となる位置を分断予定線上に位置さ せ，亀裂進展経路を制御する。龟裂進展経路を制御する ためのこれらのような新しい加工法の創出にも, 数值解 析が利用されている.

\section{6. おわりに}

レーザー照射によって誘起される熱応力を利用したガ ラスの分断加工は，基板の温度分布を制御し，その結果 生じる熱応力を利用してガラス内に亀裂を形成する加工 である。本加工は，ガラスの高い端面強度を保つことが できる点で優れた加工である。この加工の多くの場合に

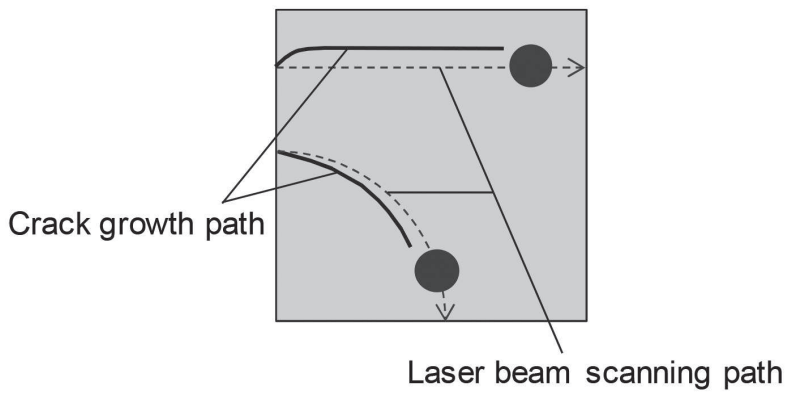

Fig. 10 Schematic of positional relation between laser scanning path and crack growth path.

おいて，亀裂は，応力拡大係数の評価によって予測され る通りに進展する。応力拡大係数を求めるには有限要素 法や境界要素法による数值解析が有効である.

基板の種類や厚さ，および分断形状によっては，意図 した通りに亀裂を進展させることが困難な場合も存在す る.このような場合には, 数值解析が原因解明に貢献す ることが期待される，数值解析の応用により，龟裂を意 図した通りに進展させるための新しい加熱・冷却方法が 提案され，より自由度の高い分断加工が実現することに 期待したい.

\section{参考文献}

1) V. S. Kondratenko: US Patent 5609284 (1997).

2）山本 幸司, 羽阪 登, 森田 英毅, 大村 悦二：精密工学会誌 論文集 71 (2005) 1157.

3) R. M. Lumley: Am. Ceram. Soc. Bull. 48 (1969) 850.

4) C. H. Tsai and C. S. Liou: J. Manuf. Sci. Eng. 125 (2003) 519

5) K. Yahata, K. Yamamoto, and E. Ohmura: J. Laser Micro/Nanoeng. 5 (2010) 109.

6）八幡恵輔, 大村 悦二, 清水 政二, 村上 政直：レーザ加工 学会誌 20 (2013) 46.

7) Y. Miyashita, M. Mogi, H. Hasegawa, S. Sujatanond, and Y. Mutoh: J. Solid Mech. Mater. Eng. 2 (2008) 1555.

8) 本村 文孝, 今井 康文, 才本 明秀：精密工学会誌 75 (2009) 1350.

9) R. Kitamura, L. Pilon, and M. Jonasz: Appl. Opt. 46 (2007) 8118.

10) 岡村弘之: 線形破壊力学入門(培風館, 1976).

11) F. Erdogan and G. Sih: J. Basic Eng. 85 (1963) 519.

12) S. K. Chan, I. S. Tuba, and W. K. Wilson: Eng. Frac. Mech. 2 (1970) 1.

13) C. F. Shih, H. G. Lorenzi, and M. D. German: Int. J. Frac. 12 (1976) 647.

14) R. S. Barsoum: Int. J. Numer. Meth. Engng. 10 (1976) 25.

15) Z. H. Jia, D. J. Shippy, and F. J. Rizzo: Int. J. Numer. Meth. Eng. 28 (1989) 2257.

16) A. Portela, M. H. Aliabadi, and D. P. Rooke: Int. J. Comput. Struct. 46 (1993) 237.

17) D. Della-Ventura and R. N. L. Smith: Int. J. Numer. Meth. Eng. 42 (1998) 927.

18) Y. Xiangqiao: Appl. Math. Model. 34 (2010) 2272.

19）山本 幸司, 羽阪 登, 森田 秀毅, 大村 悦二：レーザ加工学 会誌 15 (2008) 277.

20) K. Yahata, E. Ohmura, S. Shimizu, and M. Murakami: Proc. 31st Int. Congress on Applications of Lasers \& Electro-Optics, Anaheim, (2012) 1281.

21) C. H. Tsai and C. S. Liou: Int. J. Adv. Manuf. Technol. 18 (2001) 724. 